\title{
From selective tidal transport to counter-current swimming during watershed colonisation: an impossible step for young-of-the-year catadromous fish?
}

\author{
T. Trancart ${ }^{(1), \star}$, P. Lambert ${ }^{(1)}$, F. Daverat ${ }^{(1)}$, E. Rochard ${ }^{(1)}$
}

Received September 4, 2013

Revised November 12, 2013

Accepted November 13, 2013

Key-words: Behavioural shift, Migration, Anguilla Anguilla, Liza ramada, tidal limit

\section{ABSTRACT}

During watershed colonisation by catadromous species, two main phases have been identified: tidal estuary crossing and non-tidal river colonisation. Fishes use selective tidal-stream transport (STST) during the first phase of this colonisation, and counter-current swimming during the second phase. Therefore, catadromous species have to achieve a behavioural shift, from STST to constant counter-current swimming. This has not yet been observed, and the location and period of this shift is still unknown. Our experimental protocol aimed to mimic the spatial progression of crossing the tidal limit within a 3-week experiment. Two catadromous fishes, thinlip mullets and European eels, were initially subjected to current reversal every $6.2 \mathrm{~h}$ during the first week. A gradual tidal distortion was performed during the second week, and fishes were submitted to a unidirectional water current during the third week. Our results reveal that all catadromous species use STST as far as possible within the tidal limit. At this point, in this experimental study, no young-of-the-year (YOY) fishes shifted from STST to constant counter-current swimming. This confirms that the behavioural shift occurs later, and that the second part of the upstream migration, counter-current progression, is performed by larger, older fishes and not YOY fishes.

\section{RÉSUMÉ}

Passer d'un transport tidal sélectif à une nage à contre-courant : une étape impossible pour les poissons catadromes de l'année?

Mots-clés :

Bascule comportementale, Migration,

Anguilla

Anguilla, Liza ramada, limite tidale
Deux phases principales ont été préalablement identifiées lors de la colonisation des bassins versants par les migrateurs amphihalins thalassotoques. Ces espèces utilisent le transport tidal sélectif (TTS) lors de la première phase dans l'estuaire tidal, puis une nage active à contre-courant lors de la seconde phase dans les rivières non tidales. Les thalassotoques doivent donc réaliser une bascule comportementale entre ces deux comportements. Cette bascule n'a pas encore été observée directement. Sa localisation ainsi que sa période restent inconnues encore à ce jour. Notre protocole expérimental visait à reproduire en mésocosme la traversée de la limite tidale, lors d'une expérience longue de 3 semaines. Des individus de deux espèces thalassotoques, le mulet porc et l'anguille européenne, ont été initialement soumis à une renverse de courant toutes les 6,2 heures durant une semaine. Puis une déformation progressive de l'onde de marée a été effectuée 
lors de la seconde semaine. Enfin, lors de la $3^{e}$ semaine, les poissons n'ont été soumis qu'à un seul courant unidirectionnel. Nos résultats suggèrent que les thalassotoques utilisent le TTS aussi loin que possible, jusqu'à la fin de la limite tidale. Arrivés à ce point, dans notre étude expérimentale, aucune juvénile de l'année n'a effectué la bascule comportementale pour commencer à nager à contre-courant. Cela tend à confirmer que cette bascule a lieu plus tard, et que donc la seconde phase de colonisation est effectuée uniquement par des poissons plus âgés et plus grands, et non par des juvéniles de l'année.

\section{INTRODUCTION}

Diadromous fishes are species which regularly migrate between fresh water and salt water at a specific stage of their life cycle. Within these species, catadromous fish share the particular strategy of spending most of their life cycle in fresh water and migrating towards the sea to breed (McDowall, 1988). On the East Atlantic coast, this group is composed of species with ecological, morphological and behavioural differences. Thinlip mullet Liza ramada (Risso, 1827) and European eel Anguilla anguilla (Linnaeus, 1758) are pelagic catadromous fishes distributed along the European coast. These two species spawn in the sea, and juveniles arrive on the continental shelf and gradually colonise the watersheds from the estuary mouth to the upstream parts of rivers. This watershed colonisation has two different behavioural phases.

Firstly, in tidal estuaries, catadromous species can be transported horizontally by entering the water column during one phase of the tide and descending to the bottom during the other (Forward and Tankersley, 2001; Gibson, 1978, 2003). The use of this tactic, called selective tidal-stream transport (STST), has already been reported in the European eel (Creutzberg, 1958, 1959, 1961) and thinlip mullet (Trancart et al., 2011, 2012). In their study on young eel stages, McCleave and Wippelhauser (1987) reported that juvenile eels use STST as far as the tidal limit (TL), but no circa-tidal rhythm was observed in glass eels collected just above the head of the tide. Edeline et al. (2007) studied dispersal in metamorphosing juvenile eels by sampling glass eels from the tidal limit area. The authors reported that glass eels migrated toward the freshwater area of the upper estuary using STST and accumulated at the break point of tidal streams.

Secondly, in non-tidal parts of rivers, catadromous species have to migrate upstream using counter-current progression. During this migration, catadromous species have to achieve a behavioural shift, exchanging the tidal advection for a constant counter-current progression (Edeline et al., 2007). Feunteun et al. (2003) reported that very few glass eels and elvers less than $120 \mathrm{~mm}$ ( $<1$ year) were observed above the tidal limit, indicating that the older, larger stages, and not glass eels, migrate upstream to fresh water. In another study conducted above the tidal limit, White and Knights (1997a) captured 156000 elvers and 189000 juveniles of yellow eels, but no unpigmented glass eels. These results showed that counter-current migration was not practised by young-of-the-year (YOY) eels. Because thinlip mullet is not a widely studied species, no such investigation was conducted for these fish.

In this study, we experimentally submitted YOY of two catadromous species (thinlip mullets and European eels) to conditions that mimicked the crossing of the tidal limit area to confirm that YOY eels cannot migrate upstream against the current, and to demonstrate for the first time that YOY thinlip mullets also cannot migrate upstream against the current.

\section{MATERIALS AND METHODS}

\section{> STUDY SITE}

YOY fishes were collected in the lower part of the Gironde estuary (in southwest France, $45.5256^{\circ}$ lat, $-1.0426^{\circ}$ long) on 10 March 2008 (Figure 1). Estuaries located on the East Atlantic 


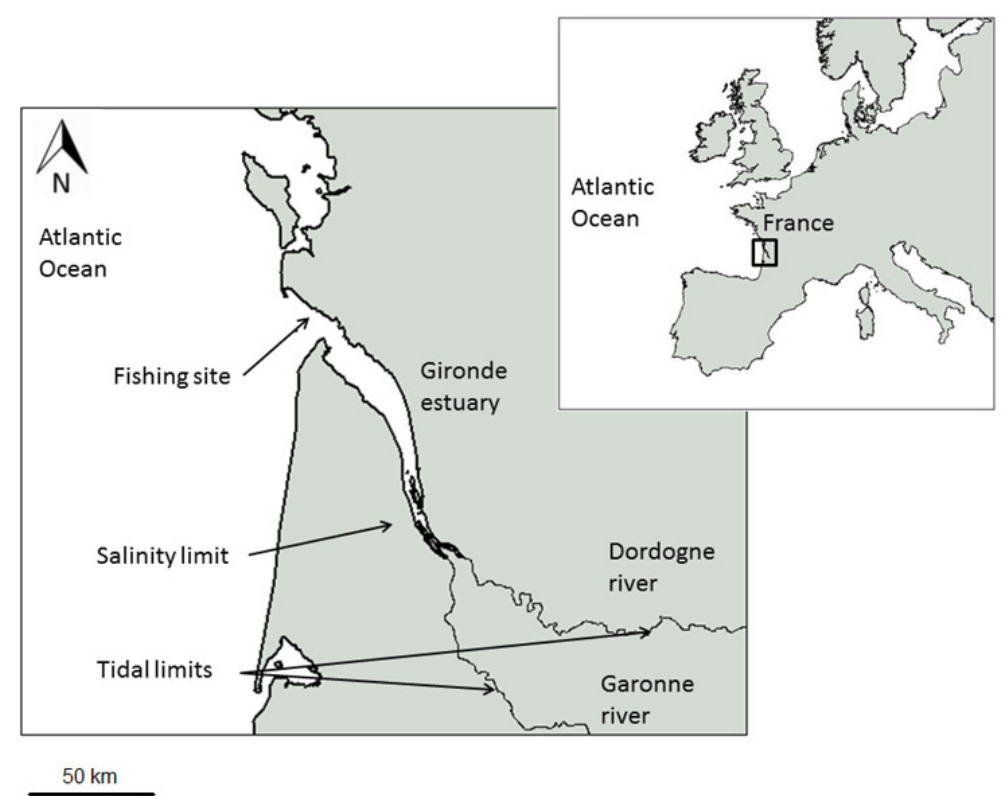

\section{Figure 1}

The study site: the Gironde system.
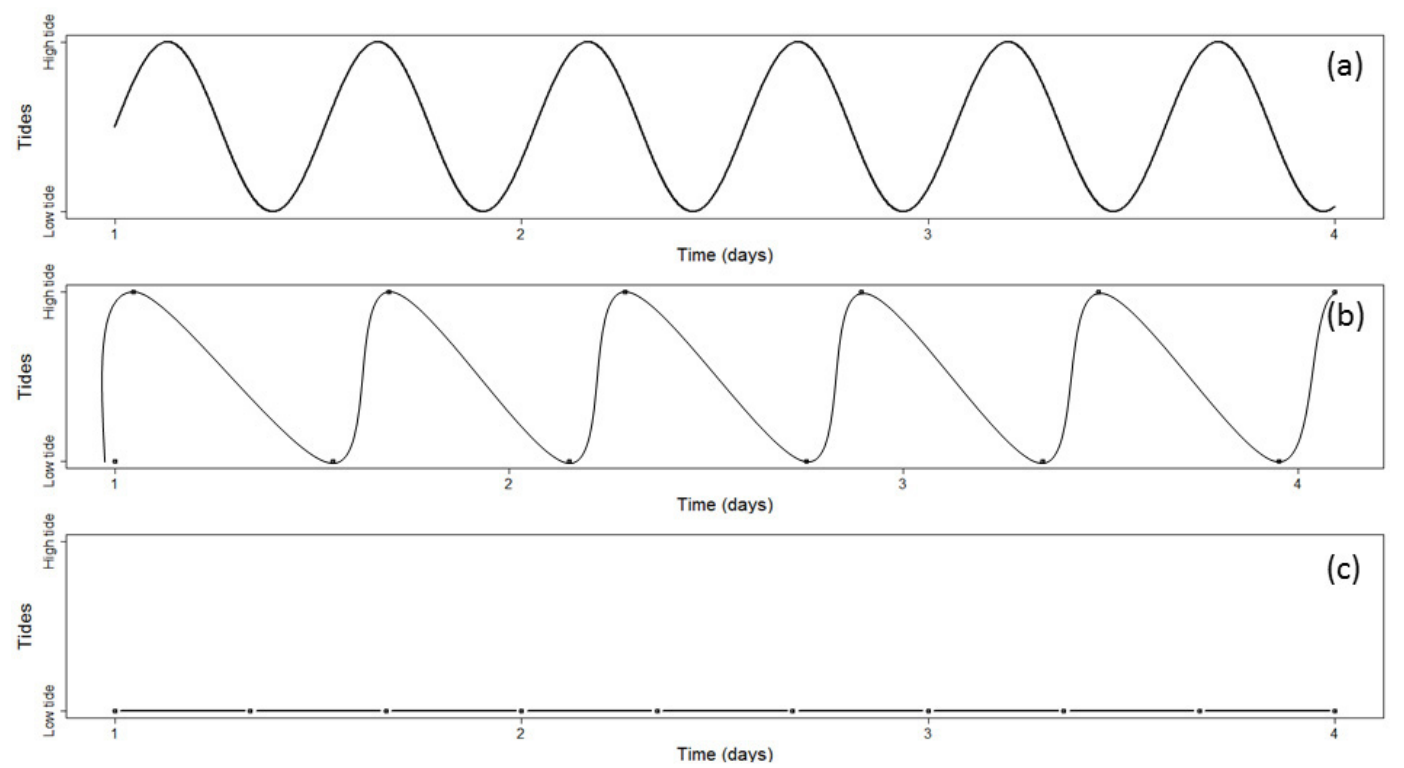

\section{Figure 2}

Example of tidal rhythms at the mouth of the estuary (a), the salinity limit (b) and the tidal limits (c) in the Gironde system.

coast are subjected to current reversal with tidal distortion. Near the mouth of the estuaries, the tidal rhythm is 6.2/6.2 h; that is, flood tides and ebb tides last $6.2 \mathrm{~h}$ (Figure 2a). At the tidal excursion limit, the water flow is always seaward: there is no tide (Figure 2c). The tidal rhythm is gradually distorted between these two points, with increasing ebb tide durations and decreasing flood tide durations. For example, in the Gironde system, at the salinity limit, flood tides last about $3 \mathrm{~h}$ and ebb tides last about $9 \mathrm{~h}$ (Figure $2 \mathrm{~b}$ ). 


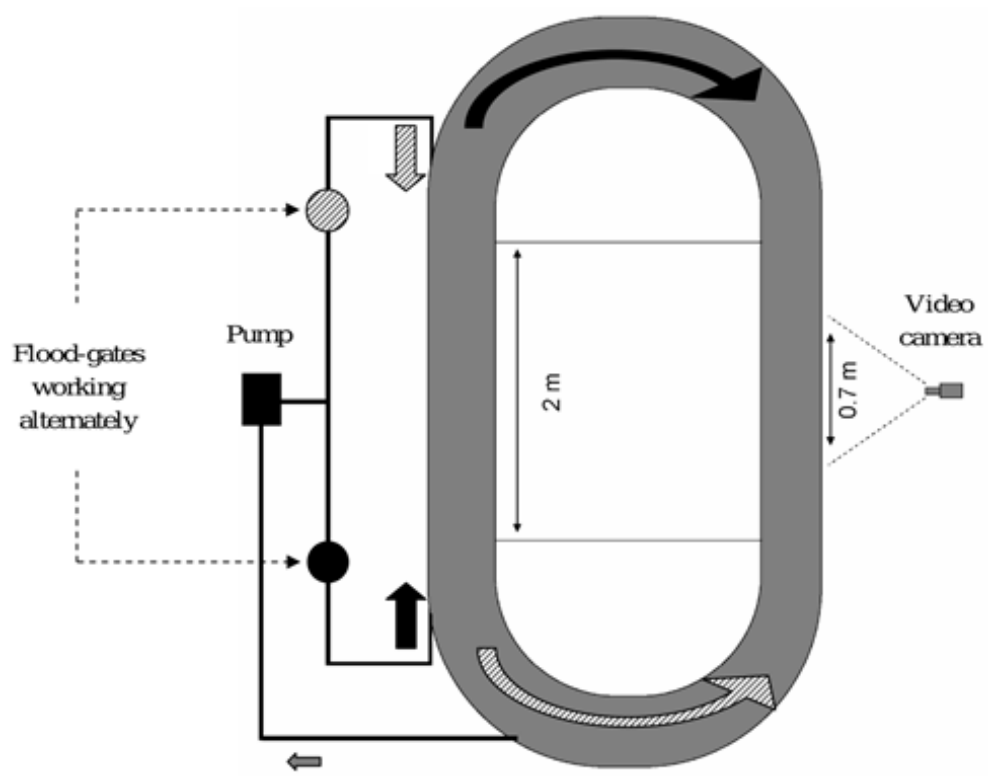

Figure 3

Diagrammatic aerial view of the annular flume.

\section{> FISH COLLECTION AND HANDLING}

YOY thinlip mullets and glass eels were caught using plankton nets $(110 \mathrm{~cm}$ diameter) during flood tides. Twenty individuals per species were randomly selected for initial biometry measures. Fish length was obtained using an electronic caliper to the nearest $\mathrm{mm}$ : YOY thinlip mullet length ranged from 19 to $37 \mathrm{~mm}$ (mean $=30.1, \mathrm{sd}=6.7 \mathrm{~mm}$ ) and glass eels ranged from 63 to $72 \mathrm{~mm}$ (mean $=67.4$, sd $=2.7 \mathrm{~mm}$ ). Fish weight was obtained using an electronic laboratory scale to the nearest $1 / 100 \mathrm{~g}$. Mullet weight ranged from 0.058 to $0.397 \mathrm{~g}$ (mean $=0.216$, $\mathrm{sd}=0.124$ ) and glass eels ranged from 0.199 to $0.317 \mathrm{~g}$ (mean $=0.254$, $\mathrm{sd}=0.038$ ). These fish were not used in the experiment. Salinity was about 15 and water temperature about $11{ }^{\circ} \mathrm{C}$ during fish collection. Mullet identification was performed using morphological criteria during sampling (using identification keys described by Farrugio (1975) and Cambrony (1983)) and using anatomical criteria at the end of the experiments (Cambrony, 1983; Farrugio, 1975). After collection, the fish were placed in an acclimation tank (light, temperature and salinity conditions similar to those at the collection site), and the experiments began when fish resumed feeding (after 2 days). Thanks to careful procedures, the mortality rate from fishing to the end of acclimation was below $10 \%$ for mullets and below $2 \%$ for glass eels. Using an automatic feeder controlled by a remote terminal unit, mullets were fed artificial feed (pellets, $1.1 \mathrm{~mm}$ mean diameter) randomly every two or three days to prevent any induction of behavioural rhythms. The feed weighed $5 \%$ of the total weight of mullets in the flume. Because a number of studies have suggested that glass eels do not feed during estuarine migration (Kawakami et al., 1999; Lecomte Finiger, 1992; Tesch, 1977), glass eels were not fed during the experiments; the floating granules were out of reach. At the end of the experiment, a small number (20) was selected for the final biometry.

\section{> EXPERIMENTAL DESIGN}

The device used for fish observation consisted of one annular flume ( $8 \mathrm{~m}$ long, $0.3 \mathrm{~m}$ wide, $0.6 \mathrm{~m}$ deep, $2 \mathrm{~m}^{3}$ ) (Figure 3).

The substratum was a $5-\mathrm{cm}$ layer of gravel (1 $\mathrm{cm}$ mean diameter). A pump generated water current, and two antagonist floodgates were used to perform water current reversal. Using injectors specially developed for this device, the water current was homogeneous in the flume. 
Pumped seawater was used, and was adjusted to the initial salinity level required by adding fresh water. During the experiment, a decrease in salinity could be produced by controlled fresh water addition. Fresh water was pumped from the watershed where the fish had been collected. A Sony infra-red camera was positioned to record through an observation window in the middle of the flume. The infra-red light $(850 \mathrm{~nm})$ allowed the recording of fish during both light and dark phases.

\section{> EXPERIMENTAL PROTOCOL}

The behaviour of 65 thinlip mullets and 250 glass eels was analysed from March 13 to April 4, 2008. There was a succession of three different experimental phases that aimed to mimic the conditions found when crossing the tidal limit area.

\section{First experimental phase: synchronisation with one water current}

Initial experimental conditions during the first week were set to mimic the environmental conditions at the fishing site. The water was kept at $11 \pm 0.2{ }^{\circ} \mathrm{C}$ and was sterilised by UV light. All trials were conducted under a 12-h light/12-h dark photoperiod (L/D). The light intensity was set at $1.5 \mu \mathrm{W} \cdot \mathrm{cm}^{-2}$ during light phases (Philips fluorescent lights, cool day-light quality, $6500 \mathrm{~K})$ and $0 \mu \mathrm{W} \cdot \mathrm{cm}^{-2}$ during dark phases. Current velocity was $10 \mathrm{~cm} \cdot \mathrm{s}^{-1}$, far below the maximum swimming performance of fish of that size (Blaxter, 1969). Fish were subjected to current reversal every $6.2 \mathrm{~h}$ during this first week, which corresponded to the conditions in the lower part of estuaries (downstream, Figure 2a).

During this first week of the experiment, fish were observed to determine the water current preferentially selected for active swimming with the current. This current was called the "favourite current", while the non-preferred water current was called the "non-favourite current".

\section{Second experimental phase: selection of favourite current as flood tide}

During the second week, a gradual tidal distortion was mimicked. This gradual tidal distortion was achieved by progressively decreasing the duration of the favourite current from 6.2 to $0 \mathrm{~h}$ and by increasing the duration of the non-favourite current to continuous flow in accordance with the global periodicity of $12.4 \mathrm{~h}$. Fresh water entry was allowed only during the nonfavourite current flow to mimic the salinity decrease occurring in estuaries during the ebb tide. Fresh water was pumped from the watershed where the fish were collected. Salinity decrease was automatically controlled and adjusted, and was regulated to decrease from 15 to approximately 0 over 7 days. With these settings, the favourite current was considered to mimic flood-like tides and the non-favourite current to mimic ebb-like tides.

\section{Third experimental phase: riverine conditions}

During the third week, no current reversal was performed and salinity was kept at 0 , mimicking river conditions.

\section{> DATABASE CREATION}

A swimming fish was defined as a fish using active swimming, which is different from fish swept away by the flow. A fish was considered to behave as if migrating upstream when it was swimming with the flood-like tide or against the ebb-like tide with a non-null ground speed. On the contrary, a fish was considered to behave as if migrating downstream when 
it was swimming with the ebb-like tide or against the flood-like tide with a non-null ground speed.

During the three weeks of the experiment, behaviour was recorded for one minute every $20 \mathrm{~min}$. This was done to observe and record all fishes swimming with the current. During each recording event, an operator counted the number of fish migrating upstream, i.e., the number of fish swimming with the flow during flood tides and against during ebb tides. Fish speed was monitored daily during the analysis by using a video operator to confirm that it was constant during the 3 weeks of the experiment. Because the speed of the fish swimming against the flow was lower than that of the fish swimming with the flow, a correction factor was used to count all the fish swimming against the current, i.e., not only the fish in the observation window during the minutes of observation, but also those that were not in the window during observations. The correction factor is the ratio between the two ground speeds and was adjusted daily. The number of fish swimming against the current was corrected by multiplying the number of fish by the correction factor, usually ranging from 3 to 4 (Trancart et al., 2011, 2012).

This experimental protocol aimed to reproduce the conditions that upstream-migrating fish would encounter while moving into fresh water; it was not possible to investigate the downstream migration at the same time. Therefore, throughout this study, only fish migrating upstream were considered. The results for fish with the opposite behaviour (migrating downstream) are given for information.

\section{$>$ DATA ANALYSES}

The rhythmic analysis showed if the individuals exhibited cyclic activity, i.e., the same activity at a regular interval of time. Nevertheless, rhythmic analyses are not suitable to show what the favourite modality is. For example, a diel rhythm shows an activity peak every $24 \mathrm{~h}$, but it is impossible to know if activity occurred during the night or the day. To mitigate this issue, we analysed a second parameter: the activity level, which is the instantaneous number of fish exhibiting a specific behaviour (in this study, swimming upstream).

Migration behaviour (the proportion of fish migrating upstream) was analysed using shortterm Fourier transforms (STFT). STFT is based on the usual Fourier transform performed on an appropriate time sliding window (Allen and Rabiner, 1977). The size of the time sliding windows was adjusted to 3 days to highlight daily rhythmic behaviours and to fit in the Nyquist frequency (Nyquist, 1928). Before performing STFT, linear least-squares trends were removed, and high-frequency noise and non-linear trends were removed using a passband (1-6-30-72 h) Butterworth filter, as recommended by Dowse and Ringo (1989). STFT shows the strength of the variations (energy) of a time series at each frequency of oscillation. In other words, it decomposes the variance of a time series into its periodicities. STFT results are presented in 2D periodograms, where the most strong/powerful periods are represented in red, and the weaker periods in yellow. Actograms of swimming activity levels of fish migrating upstream were used to validate the STFT results.

Due to experimental tidal distortion, we could not compare the evolution of the total number of fish migrating upstream with the tides (there were more fish migrating during a 6.2-h tide than during a $30-\mathrm{min}$ tide). The number of fish was related to the tide duration. We obtained the "mean number of fish migrating upstream by tides" as a percentage of fish per minute, which was not linked to the tide duration. The trends of tides were analysed using the Mann-Kendall test for each of the three weeks of the experiments.

\section{RESULTS}

\section{> FISH MORTALITY}

The behaviour of 65 thinlip mullets and 250 glass eels was analysed from March 13 to April 4, 2008. Due to careful treatment, no mortality was observed in glass eels or mullets during 


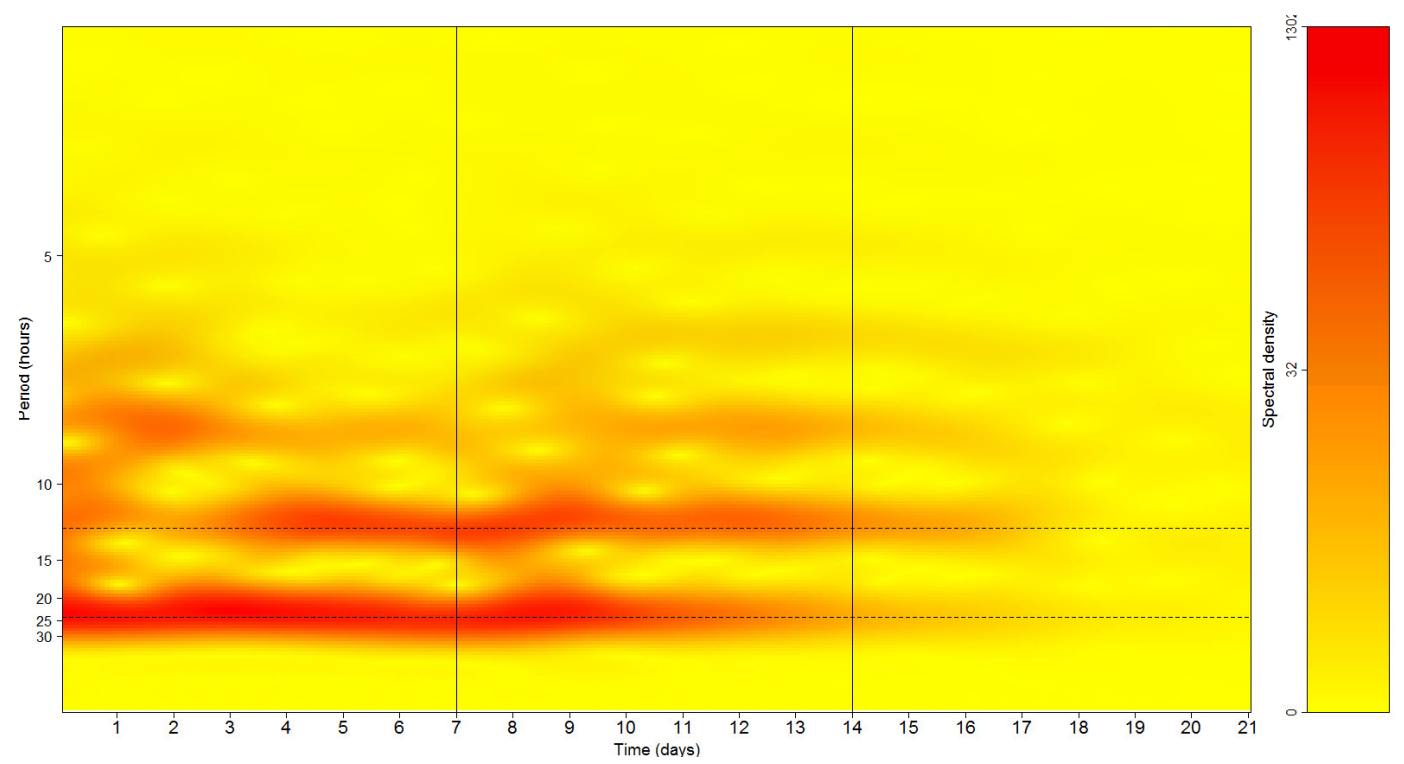

\section{Figure 4}

Periodogram based on STFT analysis for mullets migrating upstream (yellow = low density, red = high density). Dotted lines at 12.4 and $24.0 \mathrm{~h}$.

the experimental phase. No difference in weight or length was observed between the beginning and the end of the 3-week experiment in either species. However, glass eels became pigmented (or grew darker).

\section{> FIRST EXPERIMENTAL PHASE BEHAVIOURS}

During the first week, under symmetrical tidal conditions (6.2/6.2 h), mullets showed two distinct rhythmic activities, at 12.4 and $24.0 \mathrm{~h}$ (Figure 4). The main activity peak corresponded to the 24.0-h period (Figure 4).

A strong luminosity effect was observed; mullet upstream migration occurred exclusively during the daylight hours (Figure 5).

A strong tidal effect was also observed; mullets migrating upstream were active only during flood tides and inactive during ebb tides (Figure 5).

On average, around $20 \%$ of mullets migrated upstream. This percentage ranged from $50 \%$ during favourite periods (i.e., daytime flood tides for mullets) to $3 \%$ during non-favourite periods (night time). During the first week of the simulation, the number of migrating mullets was stable (Figure 5).

Like mullets, glass eels displayed two periodicities at 12.4 and $24.0 \mathrm{~h}$ (Figure 6) during the first experimental week (symmetrical tidal conditions, 6.2/6.2 h). However, in contrast to mullets, the two main rhythms had very similar intensities (Figure 6).

Unlike mullets, glass eels were active mainly during the night (Figure 7).

Like mullets, a strong tidal effect was also observed; glass eels migrating upstream were active only during flood tides and inactive during ebb tides (Figure 7).

On average, $20 \%$ of glass eels migrated upstream, similar to mullets. During favourite periods (night-time flood tides) approximately $50 \%$, and up to $90 \%$, of glass eels actively migrated upstream. During non-favourite periods (daytime), only $5 \%$ of glass eels migrated upstream, similar to mullets. 


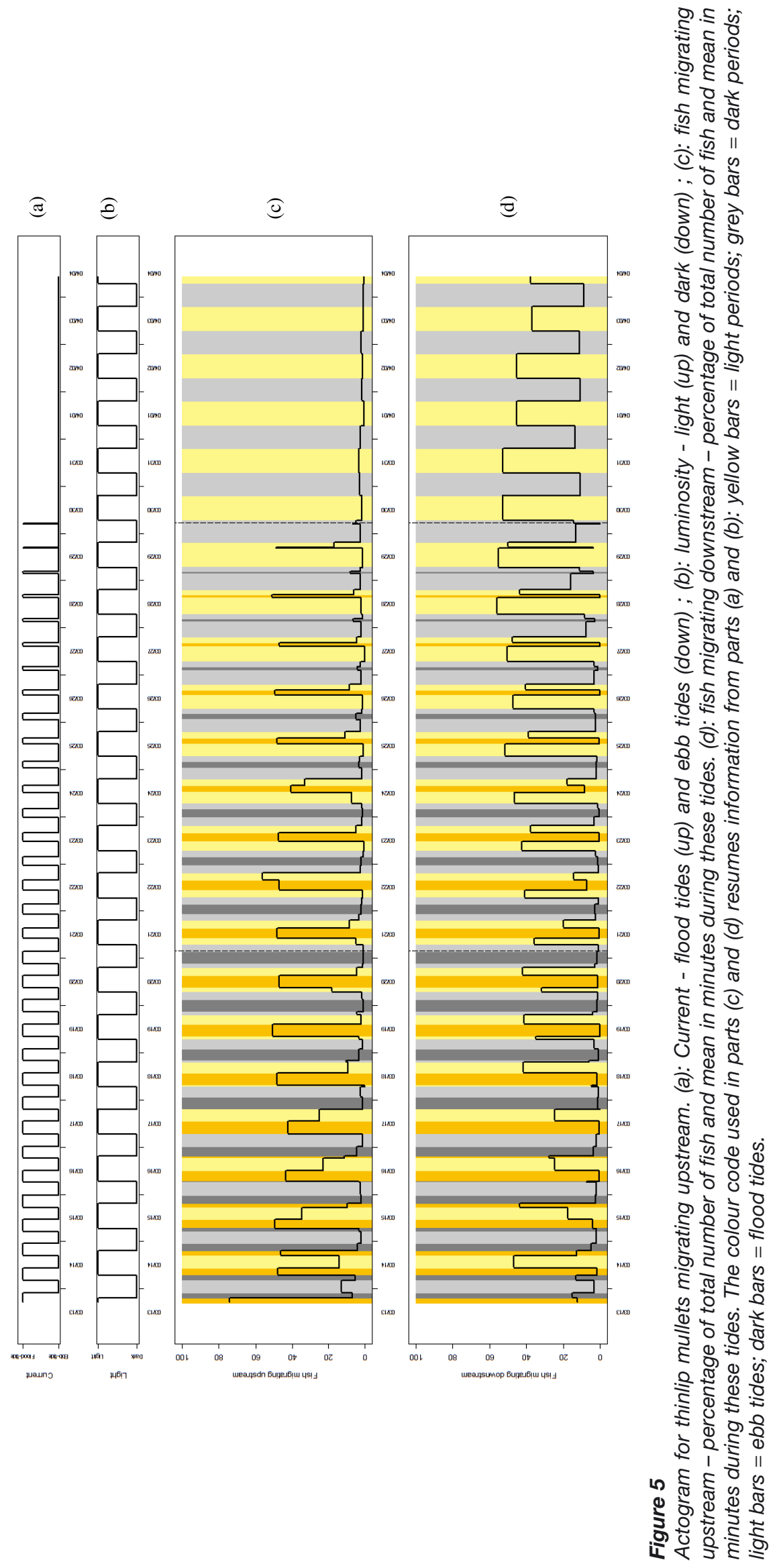




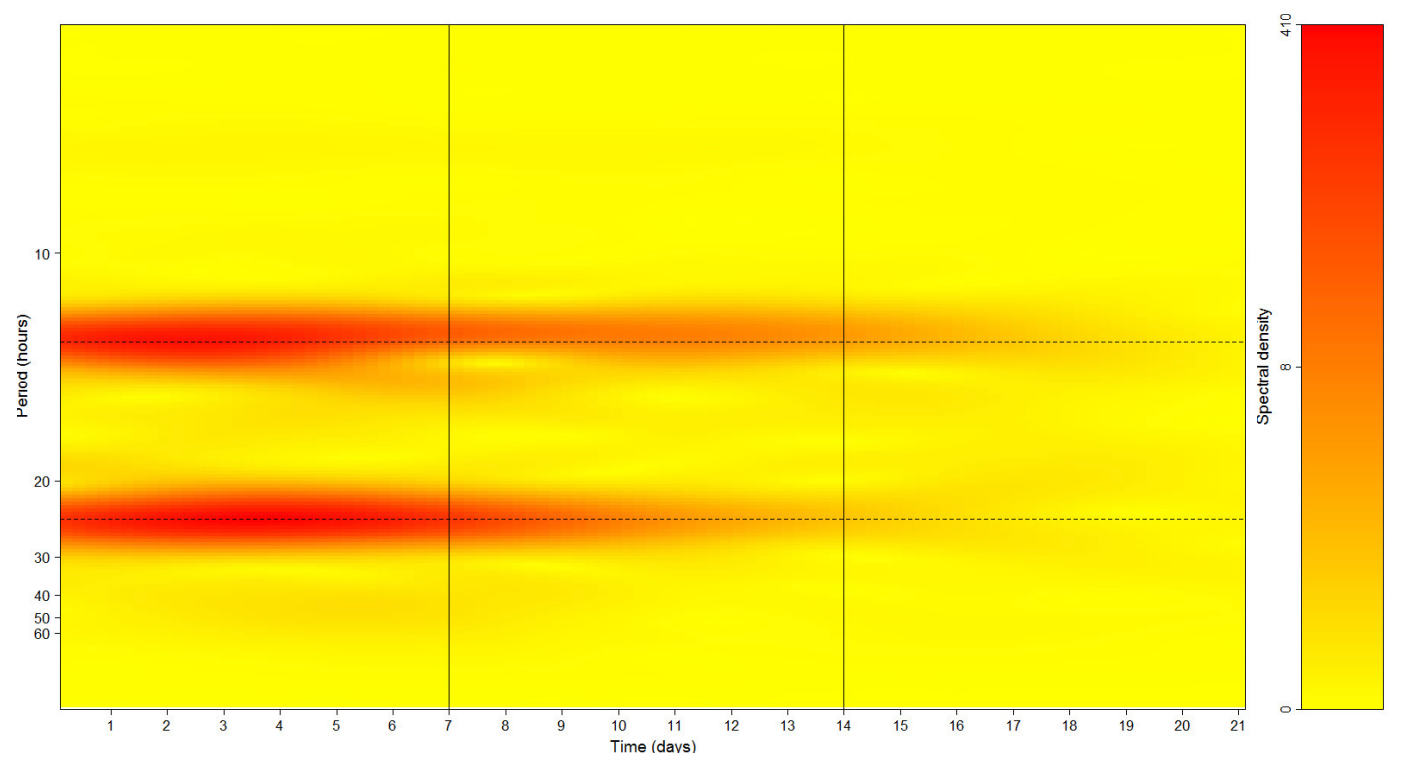

\section{Figure 6}

Periodogram based on STFT analysis for mullets migrating upstream (yellow = low density, red = high density). Dotted lines at 12.4 and $24.0 \mathrm{~h}$.

\section{> SECOND EXPERIMENTAL PHASE BEHAVIOURS}

In both species, the behaviour observed during the second week was similar to that of the first week. During the second week, cyclic activity (Figure 4) and preference for light and flood tide periods (Figure 5) always occurred.

The proportion of mullets migrating upstream was stable during simulated flood tides (Figure $5 \mathrm{c}, p<0.05$ ).

The eels' rhythms observed during the first experimental week also persisted through the second week (mimicry of tidal distortion, Figure 6). Glass eels' preferences for the night time and flood tides were always observed during the second week (during the mimicry of tidal distortion, Figure 7). This species always displayed strong nocturnal activity patterns, with upstream migration occurring predominantly during the second week at night time.

In glass eels, the mean activity levels caused by tides were constant during the second week (mimicry of tidal distortion, Figure 7c, $p<0.05$ ).

\section{> THIRD EXPERIMENTAL PHASE BEHAVIOURS}

No behavioural rhythms were observed during the third week (river conditions, without tide reversal) in either species.

After distortion, the absence of a flood tide led to a strong decline in the number of mullets and glass eels migrating upstream; the number of fish migrating upstream was close to 0 in both species. Light preferences were also not visible during the third week in either species.

\section{> ALTERNATIVE BEHAVIOURS}

This experiment was designed to mimic a progression towards the upstream of a watershed. Nevertheless, to have a better perspective, it seems necessary to include the fish that did not positively react to the experimental stimuli, i.e., fish that migrated downstream. During the first 10 days of the experiment, the number of fish that migrated downstream was lower than the number of fish that migrated upstream, in both species. During the end of the distortion 

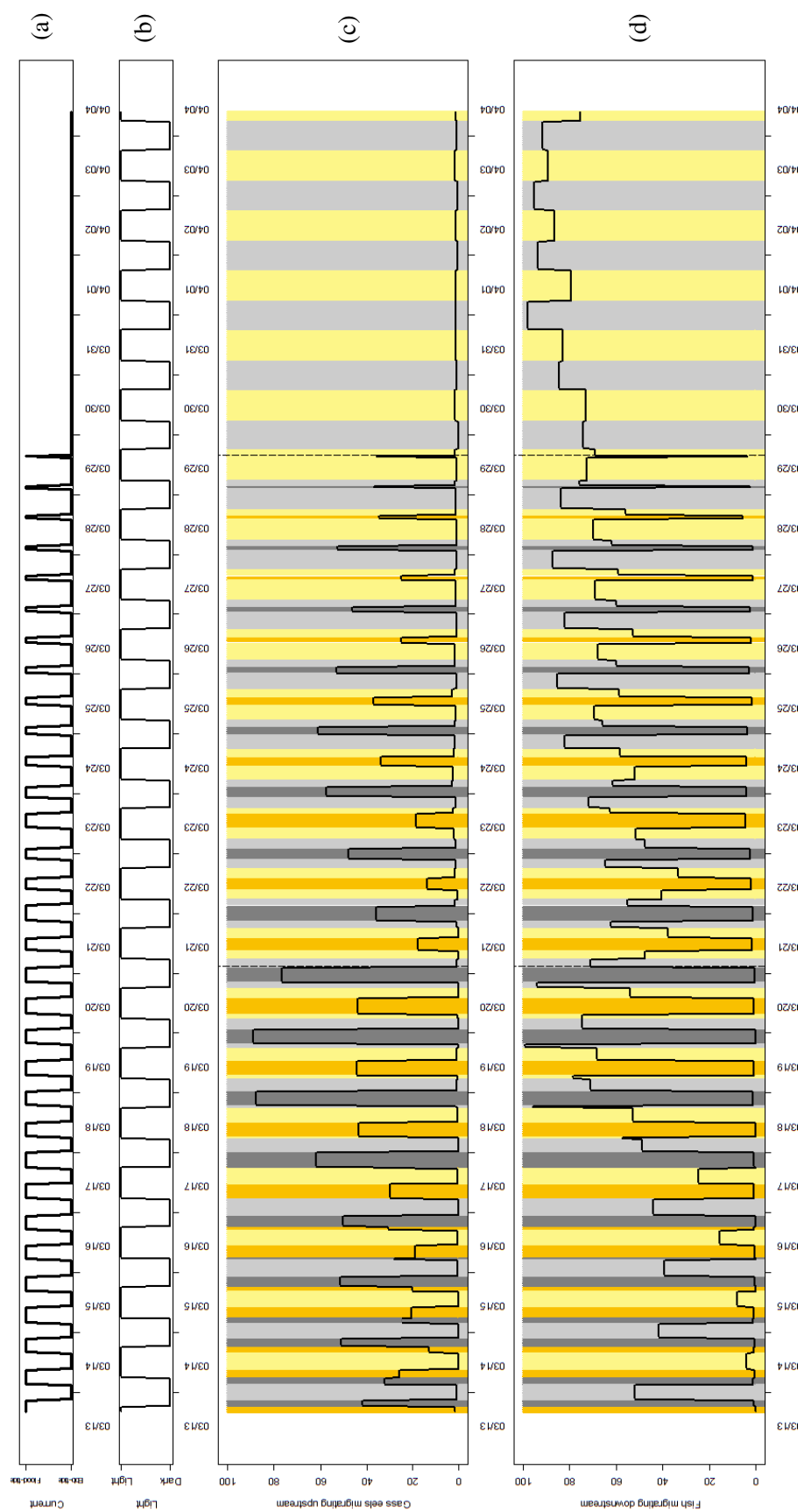

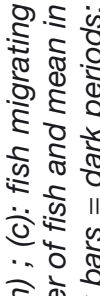

हैे बे

ठ․

竞 竞.

둥ㄴ

ำ 워

곤

\pm ल

의 छ

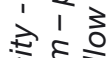

जิ ฮิ ญ

ह

خิ

$\therefore$ 이

ร

응 응

का है

ॠ

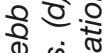

ป ฐ

สิ :

귕 워

इ क \&

क ㅇํ ऽ

$+\frac{1}{2}$

응 흐

어 \&

1 ๖

సह

\&.s

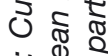

สิ่ ह .

ह่

氙

난

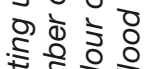

สิ है 응

के

है के

क 木 50

ब

कิ

ฮ

웡 क ?

出

วิ

ह 1 ว

人

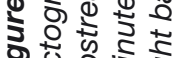

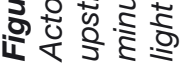


phase, the number of fish swimming downstream was higher than the number of fish migrating upstream, especially in glass eels. During the riverine conditions, the number of mullets that migrated downstream was about $50 \%$ during daytime, and about $10 \%$ during night time. The number of eels that migrated downstream during the third week was higher, about $80 \%$, with no significant difference between days and nights.

\section{DISCUSSION}

\section{> LIMITATIONS OF EXPERIMENTAL MIMICKING}

Our experiment enabled us to study the behaviour of 315 fish submitted to rigorously identical capture and experimental conditions. Because the mullet migration window is much reduced in time, no replication was performed after this experiment. Fish present again in the lower estuary could be those with alternative life histories. A recent study demonstrated that some mullets could be, like eels, facultatively catadromous, living only in the sea (Daverat et al., 2011). We assumed that by catching mullets during the beginning of the migration period, we limited the possibility of catching non-catadromous mullets.

The current experimental protocol aimed to reproduce the conditions that upstream-migrating fish would encounter while migrating to fresh water; it was not possible to investigate the downstream migration at the same time. Therefore, throughout this study, only fish migrating upstream were considered.

These major issues of experimental simulation have to be taken into account, and thus care must be taken when drawing conclusions about natural systems from laboratory simulations.

\section{>BEHAVIOURAL RHYTHMS PRIOR TO EXPERIMENTAL TIDAL DISTORTION: VALIDATION OF THE EXPERIMENTAL SET-UP}

Before the experimental tidal distortion, mullet migrating upstream exhibited periodic activity. Two rhythms were detected with periodicities of approximately $12.4 \mathrm{~h}$ and $24 \mathrm{~h}$. Because the periodicities of these rhythms coincide with changes in the flood and light cycles, it was concluded that the mullets in this study undertook diurnal flood tide transport. This is consistent with previous experimental studies carried out following the same structure (Trancart et al., 2011, 2012).

The second catadromous species, the European eel, being predominantly nocturnally active, undertook this activity during the night time. The same periodicity was observed at $12.4 \mathrm{~h}$, coinciding with changes in the flood cycles. These observations can be interpreted as being like nocturnal flood tide transport. The use of selective tidal-stream transport (STST) has already been reported in the European eel (Bolliet et al., 2007; Creutzberg, 1958, 1959, 1961). Actograms showed that the proportion of fish migrating upstream was variable, with a mean of $20 \%$ (50\% during favourite periods (daytime in mullets and night time in glass eels) and $3-5 \%$ during non-favourite periods). This is in agreement with a recent study showing that the efficiency of migration of glass eels ranged between 0.15 and 0.19 , indicating that glass eels use STST for every 5-6 flood tides.

It is well known that in glass eels, upstream migration is guided by chemotaxis (Tosi and Sola, 1993; Tosi et al., 1990). Some amino acids, called geosmins, are present in fresh water and can have a chemotactic attraction (Tos and Sola, 1993). In our experiment, we used fresh water pumped from the upper part of the Gironde watershed. It is reasonable to assume that geosmins were present in the fresh water used in our experiment.

Moreover, an increase in pigmentation was observed in glass eels during the 3-week experiment. This pigmentation is normal in field conditions, and occurs when glass eels reach freshwater areas. Moreover, no difference in weight or length was observed over the three weeks in either species. This seems plausible for the young mullets, which were fed during 
the experiment, but not for glass eels. A recent study showed that during silver eel migration, their energy consumption was very low, 4-6 times more efficient than salmonids (Palstra and van den Thillart, 2010). During watershed colonisation, fish use selective tidal-stream transport to reduce the cost of their movements (Forward and Tankersley, 2001). Active swimming with the current is much reduced, and thereby energy consumption too is reduced, leading to no observed weight loss after 3 weeks of swimming without food.

These results in both species show the effectiveness of this experimental protocol to mimic estuarine conditions. The fact that the results obtained in this study under experimental conditions are in agreement with observations on wild individuals demonstrates the appropriateness of this approach and adds significance to the results reported here.

\section{> CONFIRMATION THAT THE BEHAVIOURAL SHIFT DID NOT OCCUR IN YOUNG-OF-THE-YEAR FISHES}

Some previous studies on eels suggested that the shift did not occur in YOY fishes. For instance, in a field study, Edeline et al. (2007) showed that glass eels accumulated at the break point of tidal streams. Furthermore, Feunteun et al. (2003) showed that very few glass eels and elvers less than $120 \mathrm{~mm}(<1$ year) were observed above the tidal limit, indicating that older and larger eels, and not glass eels, performed upstream migration to fresh water. In another field study conducted above the tidal limit, White and Knights (1997a) captured 156000 elvers and 189000 juveniles of the yellow eel, but no unpigmented glass eels. These studies support the assumption of a halt in inward migration.

The fish that migrated downstream during the third week were very numerous, especially in eels. During this period, no great difference was observed between days and nights in eels, unlike in the first two weeks. A great difference was observed in mullets, but the mullets also migrated during the night, unlike in the first two weeks. These two observations led to the conclusion that the fishes were disturbed by the end of the distortion. We assume that this disturbance is a result of the discrepancy between the experimental simulation (the tidal distortion continued) and fish behaviour (they did not continue migrating upstream). Therefore, it is impossible to draw conclusions about fish behaviour at the tidal limit, except that YOY catadromous fishes did not shift to counter-current swimming.

Our study experimentally confirms the assumption that the shift in migration occurred at the later stage of life in catadromous species; YOY catadromous fish in the field used STST until the tidal limit but did not shift to counter-current swimming at this moment. It is likely that the shift occurs later, when the fish are older and bigger. Another assumption could be the waiting for external cues, such as temperature or photoperiod. In a previous study, White and Knights (1997b) showed this glass eel accumulation and suggested that water temperature and photoperiod might also be important cues to trigger the watershed colonisation.

\section{CONCLUSIONS}

Watershed colonisation by catadromous species comprises two phases: tidal estuary crossing and non-tidal river progression. A different behaviour is demonstrated during each phase. During the tidal estuary crossing, YOY fishes use selective tidal-stream transport. During non-tidal river colonisation, fishes use counter-current progression. Fish have to achieve a behavioural shift between these two phases.

To the best of our knowledge, we experimentally confirmed for the first time the absence of a behavioural shift, from selective tidal-stream transport to counter-current swimming, in YOY catadromous fishes. We experimentally confirmed this assumption:

- The first phase of watershed colonisation, tidal estuary crossing, is performed by YOY fish.

- The second phase of watershed colonisation, non-tidal river colonisation, is performed by older fishes with better swimming capacity. 
The proposed hypothesis can be tested by surveying glass eels and mullets throughout the tidal limit area and lower sections of riverine habitats. The presence of fish in varying sizes and developmental stages in the lower reaches of the river would validate this and would highlight such areas as priority areas for the protection and management of catadromous species.

\section{ACKNOWLEDGEMENTS}

The authors would like to thank Dr Nicolas Pade (Marine Biological Association of the UK) for improving the English of this paper, and relevant scientific comments. The present study was partly financed by the regional council of "Aquitaine" and the public interest group (GIP) "Seine Aval".

\section{REFERENCES}

Allen J.B. and Rabiner L.R., 1977. Unified approach to short-time fourier-analysis and synthesis. Proc. IEEE 65, 1558-1564.

Beaulaton L. and Castelnaud G., 2005. The efficiency of selective tidal stream transport in glass eel entering the gironde (France). Bulletin Francais de la Pêche et de la Protection des Milieux Aquatiques, 5-21.

Blaxter J.H.S., 1969. Swimming speeds of fish. FAO Fish. Rep., 2.

Bolliet V., Lambert P., Rives J. and Bardonnet A., 2007. Rhythmic swimming activity in Anguilla anguilla glass eels. Synchronisation to water current reversal under laboratory conditions. J. Exp. Mar. Biol. Ecol., 344, 54-66.

Cambrony M., 1983. Recrutement et biologie des stades juvéniles de mugilidae (Poissons Téléostéens) dans trois milieux lagunaires du Roussillon et du Narbonnais (Sales - Leucate, Lapalme, Bourdigou). Laboratoire de Biologie Marine. Université de Perpignan, 285.

Creutzberg F., 1958. Use of tidal streams by migrating elvers (Anguilla vulgaris Turt.). Nature, 181, 357-358.

Creutzberg F., 1959. Discrimination between ebb and flood tide in migrating elvers (Anguilla vulgaris Turt.) by means of olfactory perception. Nature, 184, 1961-1962.

Creutzberg F., 1961. On the orientation of migrating elvers (Anguilla vulgaris Turt.) in a tidal area. Neth. J. Sea Res., 1, 257-302.

Daverat F., Martin J., Fablet R. and Pecheyran C., 2011. Colonisation tactics of three temperate catadromous species, Eel Anguilla anguilla, mullet Liza ramada and flounder Platychthys flesus, revealed by Bayesian multielemental otolith microchemistry approach. Ecol. Freshw. Fish, 20, 42-51.

Dowse H.B. and Ringo J.M., 1989. The search for hidden periodicities in biological time series revisited. J. Theor. Biol., 139, 487-515.

Edeline E., Beaulaton L., Le Barh R. and Elie P., 2007. Dispersal in metamorphosing juvenile eel Anguilla anguilla. Mar. Ecol. Prog. Ser., 344.

Farrugio H., 1975. Les muges (Poissons, Téléostéens) de Tunisie. Répartition et pêche, contribution à leur étude systématique et biologique. Université des Sciences et Techniques du Languedoc, 201.

Feunteun E., Laffaille P., Robinet T., Briand C., Baisez A., Olivier J.M. and Acou A., 2003. A review of upstream migration and movements in inland waters by anguillid eels. Towards a general theory. In: Aida K., Tsukamoto K. and Yamauchi K. (eds.), Eel Biology. Springer-Verlag, Tokyo, 191-213.

Forward R.B. and Tankersley R.A., 2001. Selective tidal-stream transport of marine animals. Oceanogr. Mar. Biol. Annu. Rev., 39, 305-353.

Gibson R.N., 1978. Lunar and tidal rhythms in fish. In: Thorpe J.E. (ed.), Rhythmic activity of fishes. Academic Press, New York, 201-213.

Gibson R.N., 2003. Go with the flow: tidal migration in marine animals. Hydrobiologia, 503, 153-161.

Kawakami Y., Mochioka N., Kimura R. and Nakazono A., 1999. Seasonal changes of the RNA/DNA ratio, size and lipid contents and immigration adaptability of Japanese glass-eels, Anguilla japonica, collected in northern Kyushu, Japan. J. Exp. Mar. Biol. Ecol., 238, 1-19. 
Lecomte Finiger R., 1992. Growth history and age at recruitment of European glass eels (Anguilla anguilla) as revealed by otolith microstructure. Mar. Biol., 114, 205-210.

McCleave J.D. and Wippelhauser G.S., 1987. Behavioural aspects of selective tidal stream transport in juvenile American eels. Am. Fish. Soc. Symp., 1, 138-150.

McDowall R.M., 1988. Diadromy in fishes: migration between freshwater and marine environments. Croom Helm, London. 308 p.

Nyquist H., 1928. Certain Topics in Telegraph Transmission Theory. Winter Convention of the A.I. E.E. Transactions of the A.I. E. E, New-York, 617-644.

Palstra A.P. and van den Thillart G., 2010. Swimming physiology of European silver eels (Anguilla anguilla L.): energetic costs and effects on sexual maturation and reproduction. Fish Physiol. Biochem., 36, 297-322.

Tesch F.W., 1977. The eel. Chapman and Hall, London, 434 p.

Tosi L. and Sola C., 1993. Role of geosmin, a typical inland water odor, in guiding glass eel Anguilla anguilla (L) migration. Ethology 95, 177-185.

Tosi L., Spampanato A., Sola C. and Tongiorgi P., 1990. Relation of water odour, salinity and temperature to ascent of glass-eels, Anguilla anguilla (L.): a laboratory study. J. Fish Biol., 36, 327-340.

Trancart T., Lambert P., Rochard E., Daverat F., Roqueplo C. and Coustillas J., 2011. Swimming activity responses to water current reversal support selective tidal-stream transport hypothesis in juvenile thinlip mullet Liza ramada. J. Exp. Mar. Biol. Ecol., 399, 120-129.

Trancart T., Lambert P., Rochard E., Daverat F., Coustillas J. and Roqueplo C., 2012. Alternative flood tide transport tactics in catadromous species: Anguilla anguilla, Liza ramada and Platichthys flesus. Estuarine Coastal Shelf. Sci., 99, 191-198.

White E.M. and Knights B., 1997a. Dynamics of upstream migration of the European eel, Anguilla anguilla (L.), in the Rivers Severn and Avon, England, with special reference to the effects of manmade barriers. Fish. Manage. Ecol., 4, 311-324.

White E.M. and Knights B., 1997b. Environmental factors affecting migration of the European eel in the rivers Severn and Avon, England. J. Fish Biol., 50, 1104-1116. 